ISSN 1823-626X

Journal of Fundamental Sciences

available online at http://jfs.ibnusina.utm.my

\title{
Chemical Oxygen Demand reduction in industrial wastewater using locally isolated bacteria
}

\author{
Nor Syamimi Musa* and Wan Azlina Ahmad \\ Department of Chemistry, Faculty of Science, Universiti Teknologi Malaysia, 81310 UTM Skudai, Johor, Malaysia.
}

Received 3 May 2010, Revised 29 September 2010, Accepted 7 October 2010, Available online 2 November 2010

\begin{abstract}
Wastewater that has been discharged from the pineapple industry contributes to high levels of Biochemical Oxygen Demand (BOD), Chemical Oxygen Demand (COD) and Suspended Solids (SS). The high levels of COD concentrations in wastewater are toxic to biological life and will affect aquatic environment. Currently, there are many methods that have been developed to treat pineapple industry wastewater such as ozonation, reverse osmosis and filtration. However, these conventional methods are costly and generate large amounts of sludge. Biological treatment may be a good alternative since its operational cost is less and it creates an environmental friendly atmosphere compared to the conventional methods. In this study, the effectiveness of COD reduction involving a single bacterial culture D, G and I isolated from a pineapple industry wastewater were used in batch system. The COD reduction of pineapple industry wastewater was carried out using bacterial culture and pellet. The performance of these systems in reducing the COD level was monitored within 3 days. The COD reduction was analyzed using a Hach DR/4000 U spectrophotometer. The bacterial pellet D, G and I showed a maximal COD reduction of $87 \%, 77 \%$ and $94 \%$ respectively after 3 days exposure to wastewater. The wastewater treatment using bacterial pellet showed higher COD reduction as compared to treatment using whole bacterial culture. FESEM analysis showed that bacteria D, G and I appeared as rod shaped.
\end{abstract}

| Batch System | Biological Treatment | Chemical Oxygen Demand | FESEM | Pineapple Industry Wastewater |

( 2010 Ibnu Sina Institute. All rights reserved. http://dx.doi.org/10.11113/mjfas.v6n2.188

\section{INTRODUCTION}

The trend towards strict environmental regulation and water quality improvement has increased public awareness on quality of the environment. Wastewater discharged from various industries such as food processing industry (pineapple industry) contains hazardous and toxic chemicals, and contributes to high levels of Biochemical Oxygen Demand (BOD), Chemical Oxygen Demand (COD) and Suspended Solids (SS) [1].

Pineapple fruit (Ananas comosus) is one of the most important fruit productions, cultivated in tropical countries such as Malaysia [2]. According to the Food and Agriculture Organization (FAO) online database, Malaysia produced about 316,210 metric tons of pineapple fruits in 2007 [3]. Pineapple processing industry consumed large amounts of water at nearly every stage in the manufacturing process. As a result from these processes, the pineapple industry generated large quantities of solid and liquid wastes. The untreated release of pineapple industry wastewater contains higher amounts of carbohydrates such as sucrose, glucose and fructose which may create environmental problems when discharged into streams.

Furthermore, the concentration of COD in wastewa-

Corresponding author at: Department of Chemistry, Faculty of Science

Universiti Teknologi Malaysia, 81310 UTM Skudai, Johor, Malaysia.

E-mail addresses: nsyamimi_musa@yahoo.com (Nor Syamimi Musa) ter is mainly dependent on the total sugar content of the pineapple industry wastewater [4]. The high COD concentrations in wastewater treatment systems are toxic to biological life and will affect aquatic environment such as aquatic plants and fishes [5]. According to the Environmental Quality (Industrial Effluents) Regulations 2009, the admissible concentration of COD in wastewater for discharge must be less than $80 \mathrm{mg} / \mathrm{L}$ for standard A and $200 \mathrm{mg} / \mathrm{L}$ for standard B.

Currently, there are many methods that have been developed to treat organic pollutants in the industrial wastewater such as ozonation, chemical coagulation, reverse osmosis, membrane filtration methods, photochemical oxidation and electrochemical oxidation. However, these methods require high operational costs and energy consumption, besides producing large amounts of sludge. Therefore, biological treatment using single bacterial culture isolated from pineapple industry wastewater may be a good alternative to reduce COD in wastewater since its operational cost is lower.

\section{MATERIALS AND METHODS}

\subsection{Pineapple industry wastewater}

The pineapple industry wastewater used in this study was obtained from a pineapple processing industry at Skudai, Johor. 
The wastewater was characterised for carbohydrate, COD, color, $\mathrm{pH}$, protein, total suspended solid and turbidity.

\subsection{Bacteria}

Three types of bacteria were used in this study; bacteria D, G and I were isolated from the pineapple industry wastewater.

\subsection{Isolation of bacteria}

Single colony isolation was carried out using streak plate technique. The culture grown in Nutrient Broth medium was streaked onto the agar plate asceptically and incubated overnight at $30^{\circ} \mathrm{C}$. Repeated streaking of isolated colony was carried out to obtain a pure culture.

\subsection{Growth profile}

Growth profiles of single culture bacteria were carried out using Nutrient Broth as nutrient for bacterial growth. The single active cultures $(5 \mathrm{~mL})$ were grown in Erlenmeyer flasks $(500 \mathrm{~mL})$ containing Nutrient Broth solution $(50 \mathrm{~mL})$. All flasks were shaken at $30^{\circ} \mathrm{C}, 200 \mathrm{rpm}$ for 24 hours. Cultures $(4 \mathrm{~mL})$ were pipetted at hourly intervals into tubes for Optical Density (OD) measurement at $600 \mathrm{~nm}$ using a spectrophotometer (Genesys 20). A graph of $\mathrm{OD}_{600}$ versus time was recorded to obtain the growth curve of the single bacteria.

\subsection{COD reduction using batch system}

\subsubsection{Preparation of bacterial culture}

The COD reduction performance of pineapple industry wastewater was carried out using batch system involving bacterial culture and pellet. For the COD reduction system using bacterial culture, the single bacterial active culture $(2.5 \mathrm{~mL})$ was inoculated into Erlenmeyer flasks (250 mL) containing $25 \mathrm{~mL}$ pineapple industry wastewater, shaken at $30^{\circ} \mathrm{C}, 200 \mathrm{rpm}$ (Certomat ${ }^{\circledR} \mathrm{R}$, B.Braun) for 3 days. Samples were filtered through preweighed cellulose acetate membrane filter $(0.45 \mu \mathrm{m}$ pore size, Whatman) for COD analysis on days 1 , 2, and 3.

\subsubsection{Preparation of bacterial pellet}

The COD reduction system using bacterial pellet was carried out using an inoculation of the single bacterial active culture (30 mL) into Erlenmeyer flasks (2 L) containing 300 $\mathrm{mL}$ Nutrient Broth, shaken at $30^{\circ} \mathrm{C}, 200 \mathrm{rpm}$ for 12 hours (Certomat ${ }^{\circledR} \mathrm{R}$, B.Braun). The bacterial culture was then harvested by centrifugation at $7000 \mathrm{rpm}$ and $4^{\circ} \mathrm{C}$ for 10 minutes (B.Braun, SIGMA 4K-15). Nutrient Broth solution or supernatant was discarded from the bacterial pellet. The pellet was washed 3 times with deionised water. The bacterial pellet was then mixed into Erlenmeyer flasks (250 $\mathrm{mL}$ ) containing $25 \mathrm{~mL}$ pineapple industry wastewater. The mixture was shaken continuously at $30^{\circ} \mathrm{C}, 200 \mathrm{rpm}$ for 3 days (Certomat ${ }^{\circledR} \mathrm{R}$, B.Braun). The mixture was then centrifuged to collect supernatant for COD analysis at 1,2 , and 3 days using a (Hach DR/4000 U) spectrophotometer.

\subsection{Preparation of sample for COD analysis}

The apparatus used was COD reactor and a (Hach $\mathrm{DR} / 4000 \mathrm{U})$ spectrophotometer in which diluted samples $(2.0 \mathrm{~mL})$ was contacted, in a vial, with the mercury sulphate, (3.5 $\mathrm{mL})$ acid silver sulphate and $(1.5 \mathrm{~mL})$ standard potassium dichromate which was then heated at $150^{\circ} \mathrm{C}$ for two hours. After cooling the sample was then analyzed in the spectrophotometer at $620 \mathrm{~nm}$ [6].

\subsection{FESEM analysis}

Field-Emission Scanning Electron Microscope (FESEM) analysis was carried out to analyze the shape of the isolated bacteria D, G and I. The cultures of bacteria D, $\mathrm{G}$ and I were centrifuged to obtain bacterial pellets. Then, the pellets were immersed in $2.5 \%$ glutaraldehyde between 1-2 hours and were then washed twice with deionised water. Immersion with $2 \%$ Osmium tetraoxide $\left(\mathrm{OsO}_{4}\right)$ in $0.1 \mathrm{M}$ Phosphate Buffer Saline (PBS) was carried out for 1 hour and again washed twice with deionised water. The sample was then dehydrated using increasing concentrations of ethanol $(10 \%, 30 \%, 50 \%, 70 \%$, and $100 \%)$ for 5 minutes before drying at $70-80^{\circ} \mathrm{C}$ overnight in an oven. The sample was maintained in a dessicator before viewing under the electron microscope (Hitachi S-4500 FESEM).

\section{RESULTS \& DISCUSSION}

\subsection{Pineapple industry wastewater characteristics}

In this study, carbohydrate, COD, color, $\mathrm{pH}$, protein, total suspended solid and turbidity of pineapple industry wastewater were monitored. As shown in Table 1, the COD, $\mathrm{pH}$ and total suspended solid levels did not comply with the regulated discharged values stated in Standard B (Environmental Quality (Industrial Effluents) Regulations 2009) [7]. Hence, a treatment procedure using a consortium of bacteria was applied to reduce COD in wastewater.

\subsection{The morphological features of bacteria isolated from pineapple industry wastewater}

In order to construct an efficient COD containing wastewater treatment system, COD reducing bacteria were isolated from environmental sources such as pineapple industry wastewater. Nine single colonies were isolated by the streak plate method. The differences in morphological features of colonies were identified according to Bergey's Manual of Determinative Bacteriology [8]. Table 3 shows the different types of bacteria isolated from pineapple industry wastewater. 
Table 1: Characteristics of Pineapple Industry Wastewater

\begin{tabular}{lccc}
\hline Parameters & Unit & Value & Standard B \\
\hline Carbohydrate & $\mathrm{mg} / \mathrm{L}$ & 28,000 & - \\
COD & $\mathrm{mg} / \mathrm{L}$ & $50,000-80,000$ & 200 \\
Color & $\mathrm{Pt}-\mathrm{Co}$ & 830 & - \\
$\mathrm{pH}$ & - & 3.5 & $5.5-9.0$ \\
Protein & $\mathrm{mg} / \mathrm{L}$ & 871 & - \\
Total Suspended Solid & $\mathrm{mg} / \mathrm{L}$ & 2,810 & 100 \\
Turbidity & $\mathrm{NTU}$ & 2,253 & - \\
\hline
\end{tabular}

The Gram Stain is the most useful and widely employed stain in bacteriology. This method divides bacteria into two groups which are gram negative or gram positive. From Table 3, bacteria A, B, E, F, G, H and I were confirmed as gram negative bacteria. This is due to the appearance of the pinkish color in the bacteria cell from the slide. Gram negative bacteria do not retain the crystal violet stain and remain colorless until counterstained with safranin and then appear pink in color. Bacteria A, B, E, F, G, H and I contain a thin layer of lipopolysaccharide (lipids and polysaccharides) as part of their cell wall whereas bacteria $\mathrm{C}$ and $\mathrm{D}$ were classified as gram positive bacteria as it retains the color of the crystal violet and appeared as purple. Gram positive bacteria have a thicker cell wall than the gram negative bacteria and can be killed easily by penicillins and cephalosporins. On the other hand, gram negative bacteria are generally more resistant because the antibiotics cannot penetrate the lipopolysaccharide layer [9].

Table 3: Characteristic Features of Bacteria Isolated from Pineapple Industry Wastewater

\begin{tabular}{|c|c|c|c|c|c|c|c|}
\hline Bacteria I.D. & Form & Elevation & Margin & Surface & Opacity & Pigmentation & Bacteria Gram \\
\hline $\mathrm{A}$ & Circular & Raised & Entire & Smooth & Translucent & Pale Cream & negative \\
\hline B & Circular & Convex & Entire & Smooth & Translucent & Yellow & negative \\
\hline $\mathrm{C}$ & Irregular & Flat & Undulate & Wrinkled & Iridescent & Light Cream & positive \\
\hline $\mathrm{D}$ & Filamentous & Flat & Filiform & Wrinkled & Translucent & Yellow & positive \\
\hline $\mathrm{E}$ & Circular & Raised & Entire & Smooth & Translucent & Cream & negative \\
\hline $\mathrm{F}$ & Circular & Raised & Entire & Smooth & Translucent & Red & negative \\
\hline G & Circular & Convex & Entire & Smooth & Iridescent & Cream & negative \\
\hline $\mathrm{H}$ & Circular & Raised & Entire & Smooth & Translucent & Light Cream & negative \\
\hline I & Circular & Raised & Entire & Smooth & Translucent & White & negative \\
\hline
\end{tabular}

\subsection{Identification of the efficient COD reducing bacteria using batch system}

The COD reduction was carried out in batch system consisting of single bacteria A, B, C, D, E, G, H and I, isolated from pineapple industry wastewater. The performance of COD reduction was monitored after 24 hours to identify the most efficient bacteria for COD removal in pineapple industry wastewater. Table 4 shows the result for COD values after treatment by using single bacteria in batch system after 24 hours.

From Table 4, it was observed that the COD reduction was $33.63 \%$, 33.33\% and $30.93 \%$ for the system containing single bacteria D, G and I respectively. This result shows that bacteria $D, G$ and I in a batch system were able to degrade organic matter in pineapple industry wastewater. The bacteria D, G and I were identified as the most efficient bacteria for COD reduction and will be used for further experiment using batch and column systems.

Table 4: Percentage of COD Reduction by using Bacteria Isolated from Pineapple Industry Wastewater

\begin{tabular}{cccc}
\hline \multirow{2}{*}{ Bacteria I.D. } & \multicolumn{2}{c}{ COD Reading (mg/L) } & \multirow{2}{*}{$\begin{array}{c}\text { Percentage } \\
\text { COD } \\
\text { Reduction (\%) }\end{array}$} \\
\cline { 2 - 3 } (Initial) & (Final) & 18.60 \\
A & 68,850 & 55,800 & 16.00 \\
B & 68,850 & 57,550 & 17.90 \\
C & 68,850 & 56,250 & 33.63 \\
D & 68,850 & 45,500 & 25.46 \\
E & 68,850 & 51,100 & 33.33 \\
G & 68,850 & 45,700 & 28.88 \\
H & 68,850 & 48,750 & 30.93 \\
I & 68,850 & 47,350 & \\
\hline
\end{tabular}

\subsection{Growth profile of bacteria D, G and I}

The growth profiles of three different isolated bacteria namely bacteria D, G, and I were monitored based on optical density measurement at $600 \mathrm{~nm}$ at various intervals for 24 hours using Nutrient Broth as nutrient for bacterial growth.

The growth of these bacteria shows a typical growth curve consisting of four distinct phases of bacterial growth such as lag phase, exponential phase, stationary phase and death phase. Most microorganisms grow exponentially, but rates of exponential growth vary greatly and can be influenced by environmental conditions such as temperature and components of the culture medium as well as the genetic characteristics of the bacteria itself [10].

The time required for all bacteria to reach the stationary phase was between 12 to 14 hours. During stationary phase, the growth rate slows as bacteria consume available substrates and living space becomes limited [11]. From this study, the highest OD readings of bacteria D, bacteria $\mathrm{G}$, and bacteria I were 1.204, 1.311 and 1.283 respectively. OD unit is proportional to cell number, hence a turbid culture is associated with high OD.

\subsection{FESEM profile of bacteria D, G and I}

The single bacteria D, G and I were characterized for morphological features using the FESEM analysis. The bacteria D, G and I culture were grown in Nutrient Broth and centrifuged to obtain the bacterial pellet. 
The bacterial pellet was analyzed using Field-Emission Scanning Electron Microscope (FESEM). From FESEM analysis (Table 5), it can be seen that bacteria D, G and I appeared as rod shaped.

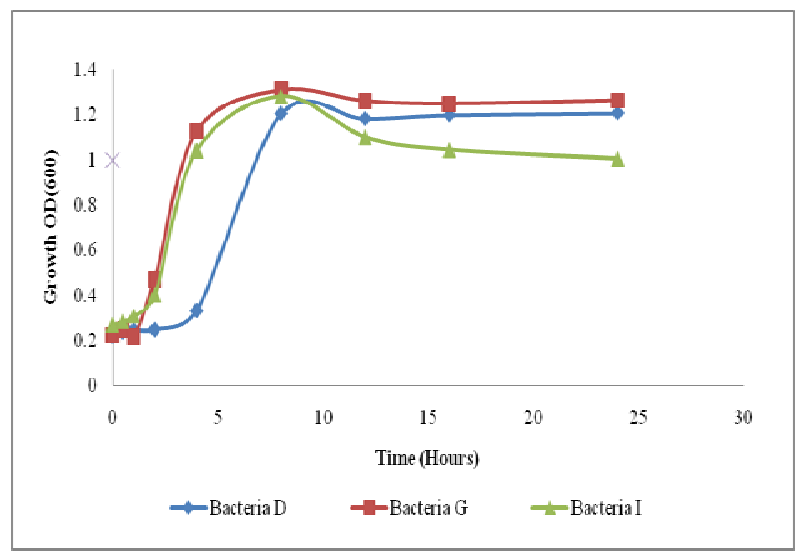

Figure 1: Growth Profiles of Bacteria D, G and I

\subsection{COD reduction in batch system}

\subsubsection{COD reduction using single bacterial culture}

The COD concentration was very high in pineapple industry wastewater compared to the permissible discharged limit according to Standard B (Environmental Quality (Sewage and Industrial Effluents) Regulations 1978). The pineapple industry wastewater was treated using single bacterial culture of bacteria D, G and I in batch system. The experiment was carried out under sterile condition. The COD reduction performance was monitored within 3 days as shown in Table 5. The initial concentration of COD in pineapple industry wastewater was $67,000 \mathrm{mg} / \mathrm{L}$ and acted as control.

From the results obtained, bacteria D, G and I which were locally isolated microorganisms from pineapple industry wastewater showed excellent COD removal capabilities. On day 3, COD reduction was observed up to $81 \%, 70 \%$ and $87 \%$ for bacteria D, G and I respectively. The results suggest that bacteria I showed the best performance in removal of COD for single bacterial culture.

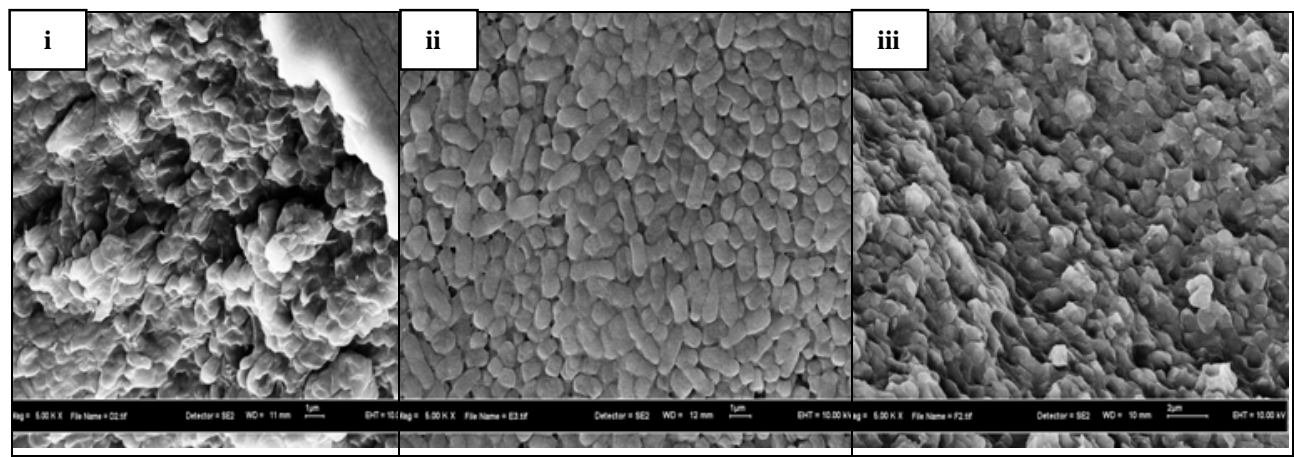

Figure 2: FESEM Micrographs of Bacteria Isolated from Pineapple Industry Wastewater: (i) Bacteria D (ii) Bacteria G (iii) Bacteria I

Table 5: COD Reduction Using Single Bacterial Culture

\begin{tabular}{ccccccc}
\hline \multirow{2}{*}{$\begin{array}{c}\text { Bacteria } \\
\text { I.D. }\end{array}$} & $\begin{array}{c}\text { COD } \\
\text { Reading } \\
\text { (mg/L) }\end{array}$ & $\begin{array}{c}\text { Day 1 } \\
\text { Reduction } \\
(\%)\end{array}$ & $\begin{array}{c}\text { COD } \\
\text { Reading } \\
(\mathbf{m g} / \mathbf{L})\end{array}$ & $\begin{array}{c}\text { COD } \\
\text { Reduction } \\
\text { (\%) }\end{array}$ & $\begin{array}{c}\text { DOD } \\
\text { Reading } \\
\text { (mg/L) }\end{array}$ & $\begin{array}{c}\text { DOD } \\
\text { Reduction } \\
\text { (\%) }\end{array}$ \\
\hline D & 49,000 & 27 & 14,850 & 78 & 13,052 & 81 \\
G & 38,900 & 42 & 23,700 & 65 & 15,048 & 70 \\
I & 45,500 & 32 & 22,350 & 67 & 8,710 & 87 \\
\hline
\end{tabular}

Control-Pineapple Industry Wastewater: 67000 mg/L

Table 6: COD Reduction Using Single Bacterial Pellet

\begin{tabular}{ccccccc}
\hline Bacteria & \multicolumn{2}{c}{ Day 1 } & \multicolumn{2}{c}{ Day 2 } & \multicolumn{2}{c}{ Day 3 } \\
\cline { 2 - 7 } I.D. & $\begin{array}{c}\text { COD } \\
\text { Reading } \\
(\mathbf{m g} / \mathbf{L})\end{array}$ & $\begin{array}{c}\text { COD } \\
\text { Reduction } \\
\mathbf{( \% )}\end{array}$ & $\begin{array}{c}\text { COD } \\
\text { Reading } \\
(\mathbf{m g} / \mathbf{L})\end{array}$ & $\begin{array}{c}\text { COD } \\
\text { Reduction } \\
\mathbf{( \% )}\end{array}$ & $\begin{array}{c}\text { COD } \\
\text { Reading } \\
(\mathbf{m g} / \mathbf{L})\end{array}$ & $\begin{array}{c}\text { COD } \\
\text { Reduction } \\
(\%)\end{array}$ \\
\hline D & 54,670 & 29 & 33,110 & 57 & 10,250 & 87 \\
G & 50,820 & 34 & 30,800 & 60 & 17,450 & 77 \\
I & 44,600 & 42 & 15,400 & 80 & 4,450 & 94 \\
\hline
\end{tabular}

Control-Pineapple Industry Wastewater: 77000 mg/L 


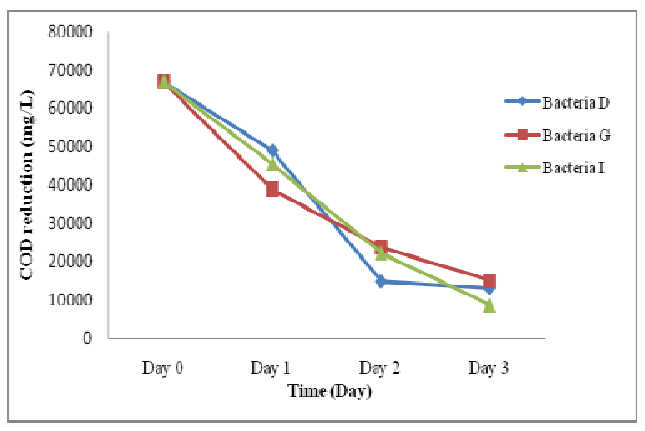

Figure 3: COD Reduction Using Single Bacterial Culture

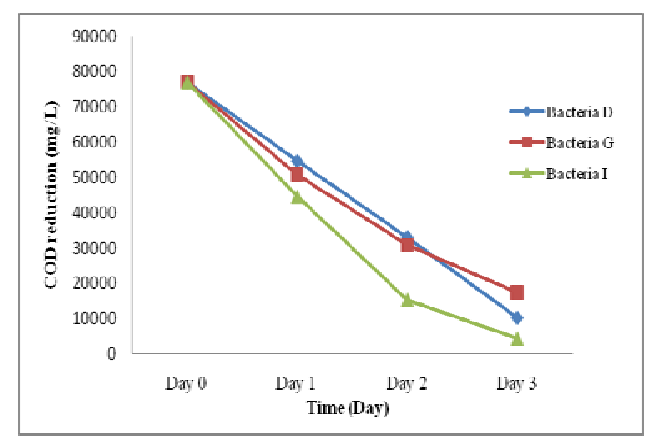

Figure 4: COD Reduction Using Single Bacterial Pellet

\subsubsection{COD reduction using bacterial pellet}

The experiment was conducted by using the pellet of bacteria D, G and I. The pellet was washed three times to make sure Nutrient Broth was removed completely. The bacterial pellet was added to the Erlenmeyer flasks containing pineapple industry wastewater and shaken for 24 hours to ensure complete COD reduction. The COD reduction performance was monitored within 3 days as shown in Table 6. The initial concentration of COD in pineapple industry wastewater was $77,000 \mathrm{mg} / \mathrm{L}$ and acted as control.

From this study, bacteria D, G and I showed $87 \%$, $77 \%$ and $94 \%$ of COD reduction respectively on day 3 . The results proposed that bacteria I showed better performance in COD reduction using bacterial pellet.

\subsection{Comparison of COD reduction performance using single bacterial culture and bacterial pellet}

The COD reduction performance of pineapple industry wastewater was monitored for 3 days using single bacterial culture and bacterial pellet. Generally, it can be seen that the system using single bacterial culture (Figure 3) and single bacterial pellet (Figure 4) removed high levels of COD effectively in the wastewater.

The results indicate that the efficiency of COD removal in pineapple industry wastewater increased by increasing treatment time. From the results obtained, the biological treatment using bacterial pellet exhibited higher
COD reduction compared to treatment using whole bacterial culture. One plausible explanation is that in the absence of Nutrient Broth, the bacteria pellet utilized the pollutants in pineapple industry wastewater as their nutrients. It was reported by Gray (2004) that the bacteria utilized the organic matter present for the production of energy by cellular respiration and for the synthesis of protein in the manufacture of new cells.

From this study, COD reduction using bacterial pellet in batch system can be applied for the industrial wastewater treatment process due to the minimum quantity of nutrient required and thus will be most cost effective [9].

\section{CONCLUSION}

The bacteria used in this study, bacteria D, G and I were locally isolated from pineapple industry wastewater. From this study, the bacterial pellet D, G and I were found to reduce $87 \%, 77 \%$ and $94 \%$ respectively of the COD level after exposure to pineapple industry wastewater within 3 days. The wastewater treatment using bacterial pellet showed higher COD reduction as compared to treatment using whole bacterial culture. FESEM analysis showed that bacteria D, G and I appeared as rod shaped.

\section{ACKNOWLEDGEMENT}

The financial support from the Ministry of Science, Technology and Innovation of Malaysia via technofund vote 79902 and NSF scholarship for Nor Syamimi Musa is gratefully acknowleged.

\section{REFERENCES}

[1] Somasiri, W., Li, X., Ruan, W. and Jian, C. (2008). Bioresource Teechnology. 99, 3692-3699

[2] Correia, R., Magalhaes, M., and Macedo, G. (2007). Journal of Scientific \& Industrial Research. 66, $259-262$

[3] Food and Agriculture Organization (FAO) of the United Nations databases

[4] Rosma, A. and Ooi, K. I. (2006). Malaysian Journal of Microbiology. 2(2), 15-18

[5] Somasiri, W., Li, X., Ruan, W. and Jian, C. (2008). Bioresource Teechnology. 99, 3692-3699

[6] Walker, G.M. and Weatherley, L.R. (2001). J. Chem. Eng. 84, 123-131.

[7] Enviromental Quality Act and Regulations Handbook. (2009). Laws of Malaysia: Details on Eniromental Quality Act 1974 and Regulations Amendments up to June 2009: Act 127 with Inde. Kuala Lumpur: MDC Publishers. 34-35.

[8] Breed, R. S. and Murray, E. G. (1984). Bergey’s Manual of Determinative Bacteriology [M], The Williams and Wilkins Company, Loudan.

[9] Tortora, G. J., Funke, B. R. and Case C. L. (2007). Microbiology an introduction. United State of America: Pearson Education, Inc. 68-71

[10] Nafisah Mohd Yusof (2007). COD Reduction in textile wastewater using biological system. Bachelor of Science. Universiti Teknologi Malaysia, Skudai.

[11] Gerardi, M. H. (2006). Wastewater Bacteria. (1 $1_{\text {st }}$ ed.). Hoboken, New Jersey: John Wiley \& Sons, Inc. 